УДК 331.107.5:656.2

\title{
ФОРМИ СТРАТЕГІЧНОГО ПАРТНЕРСТВА ПРИ РЕАЛІЗАЦІЇ ПРОЕКТІВ РОЗВИТКУ ЗАЛІЗНИЧНОЇ ІНФРАСТРУКТУРИ
}

\author{
Боровик Ю. Т., к.е.н., доцент, \\ Слагін Ю. В., к.е.н., доцент, \\ Полякова О. М., к.е.н., доцент (УкрДУЗТ)
}

B статті розглянуто сутність стратегічного партнерства та форми стратегічної взаємодії при реалізації проектів розвитку залізничної інфраструктури. Відмічено, щзо стратегічна взаємодія суб'єктів ринку здійснюється на основі довгострокового характеру, взаємодоповнюючих ключових компетенцій, щуо створюють унікальні иінності для споживачів.

Проаналізовано стан залізничної інфраструктури Украӥни та виділено особливості стратегічної взаємодії держави, бізнесу $i$ приватних інвесторів. Підкреслено важливість стратегічної співпраці на залізничному транспорті у рамках державно-приватного партнерства.

Ключові слова: стратегічне партнерство, інфраструктура, держсавноприватне партнерство, залізничний транспорт, інвестицї̈, проекти розвитку залізничної інфраструктури.

\section{ФОРМЫ СТРАТЕГИЧЕСКОГО ПАРТНЕРСТВА ПРИ РЕАЛИЗАЦИИ ПРОЕКТОВ РАЗВИТИЯ ЖЕЛЕЗНОДОРОЖНОГО ИНФРАСТРУКТУРЫ}

Боровик Ю. Т., к.э.н., доцент, Елагин Ю. В., к.э.н., доцент, Полякова Е. Н., к.э.н., доцент (УкрГУЖТ)

В статье рассмотрены сущность стратегического партнерства и формы стратегического взаимодействия при реализации проектов развития железнодорожной инфраструктуры. Отмечено, что стратегическое взаимодействие субъектов рынка осуществляется на основе долгосрочного характера, взаимодополняюших ключевых компетенщий, которые создают уникальные цеенности для потребителей.

Проанализировано состояние железнодорожной инфраструктуры Украинь и вылелень особенности стратегического взаимодействия государства, бизнеса и частных инвесторов. Подчеркнута важность стратегического сотрудничества на железнодорожном транспорте в рамках государственно-частного партнерства.

Ключевые слова: стратегическое партнерство, инфраструктура, государственно-частное партнерство, эжелезнодорожный транспорт, инвестиции, проекты развития жселезнодорожной инфраструктуры.

(C) Боровик Ю.Т.,

Єлагін Ю.В.,

Вісник економіки транспорту і промисловості № 68, 2019

Полякова О.M. 


\title{
FORMS OF STRATEGIC PARTNERSHIP IN THE IMPLEMENTATION OF RAILWAY INFRASTRUCTURE DEVELOPMENT PROJECTS
}

\author{
Borovik Y. T., Ph.D, associate professor, \\ Elagin Y. V., Ph.D, associate professor, \\ Polyakova E. N., Ph.D, associate professor (USURT)
}

The article considers the essence of strategic partnership and the forms of strategic interaction in the implementation of railway infrastructure development projects. Strategic partnership is a system of voluntary, long-term and interrelated relations of an integration type between participants in economic activity.

The problem of critical deterioration of the infrastructure of Ukraine can be solved through the interaction of Ukrzaliznytsia, the state, business and private investors. The strategic interaction of market entities is based on a long-term nature, key competencies that create unique values for consumers.

The state of the railway infrastructure of Ukraine is analyzed and the features of strategic interaction are highlighted. The main strengths of the railway infrastructure is a developed railway network, high throughput, low cost of transportation, profitability of freight traffic. Weaknesses include incomplete reform, the lack of a mechanism for the participation of a private partner in the construction of railway infrastructure, a ban on concession of main lines, unprofitable passenger transportations, bureaucratic procedures for cargo clearance for international transport. The disadvantages of the implementation of public private partnership projects are the high cost and complexity of the process, the lack of company management skills.

The importance of strategic cooperation in rail transport in the framework of publicprivate partnerships was emphasized. The main factor holding back the development of public-private partnerships in the transport industry of Ukraine is a weak regulatory framework. Other forms of implementing a strategic partnership are a stakeholder concept, a network concept, and a life cycle contract. With a variety of forms of interaction, they are designed to provide a certain benefit; however, the effect for each of the participants is best when implementing a strategic partnership.

Keywords: strategic partnership, infrastructure, public-private partnership, railway transport, investments, railway infrastructure development projects.

Постановка проблеми. Сучасна транспортна інфраструктура $є$ однією 3 найважливіших умов зростання економіки. Регіональні та національні транспортно-логістичні забезпечують ефективні транспортні, науково-виробничі та постачальницькозбутові комунікації між економічними агентами. Згідно 3 міжнародними індикаторами, які використовуються для оцінки стану ринку, мультиплікатор інвестицій у залізничний транспорт становить від 2 до 3 , а за деякими підрахунками - до 5 разів. Це означає, що інвестуючи у проект 1 долар США, можна отримати 5 доларів США у вигляді зростання ВВП [16].

В той же час за оцінкою UIF, станом на 2018 рік знос основної колії Укрзалізниці становить близько 50\% і має стримку тенденцію до зростання 3 урахування зносу попередніх років [16]. Про поступову втрату конкурентних позицій «Укрзалізницею» на світовому ринку свідчать дані The Global Competitiveness Report 2017-2018, згідно 3 якими Україна за критерієм розвитку залізничної інфраструктури посідає 37 місце, що на 12 позицій нижче порівняно 3 2014 роком. Падіння в рейтингу

Вісник економіки транспорту і промисловості № 68, 2019 
спостерігається протягом кожного року. Основною причиною втрати позицій залізничного транспорту є фізичний знос магістральних та регіональних колій [19].

Діапазон обсягів необхідних інвестицій у залізничний транспорт до 2030 року становить 31-60 млрд дол., 3 них 15-30 млрд дол. - у розвиток та оновлення інфраструктури залізничного транспорту. В той же час очікуваний ефект на ВВП до 2030 року від оновлення інфраструктури складає 30-60 млрд дол. Заплановані капітальні інвестиції у залізничний транспорт України на 20192020 р. становлять 0,9 млрд євро [19].

Одним із шляхів вирішення проблем критичного зносу інфраструктури України $\epsilon$ взаємодія Укрзалізниці, держави, бізнесу та приватних інвесторів. В останні роки отримують розвиток інтеграційні процеси підприємств і їх об'єднання за допомогою глобальних інформаційних систем в стратегічні альянси та інші союзи різних типів.

Враховуючи стратегічну значущість розвитку інфраструктури залізничного транспорту для реалізації транзитних можливостей країни, ключовим інструментом реалізації проектів розитку галузі $є$ встановлення партнерських взаємовигідних відносин між усіма учасниками транспортно-логістичного процесу. В таких умовах виникає необхідність побудови ефективної системи взаємодії і управління партнерством підприємств і організацій.

Аналіз останніх досліджень i публікацій та виділення невирішених частин загальної проблеми. Проблемам розвитку інфраструктури залізничного транспорту та аспектам утворення i функціонування стратегічних партнерств присвячено багато робіт зарубіжних i вітчизняних авторів, зокрема I. А. Альошиної, Т. М. Геращенкової, О. М. Гребешкової, Г. В. Махової, О. Затворницької, Є. В. Корольової, Є. А. Малицької, Ч. Шань та інших [3, 4, 10, 12, $13,17]$.
Питання стратегічного партнерства на залізничному транспорті та доцільність взаємодії підприємств транспорту й промисловості розглядаються в наукових працях В. Л. Диканя, Ю. В. Слагіна, В. О. Овчиннікової, І. В. Токмакової, А. В. Толстової, О. В. Шраменко [6-9, 14, 15, $18]$.

Поряд 3 цим, проблематика стратегічного партнерства, на відміну від інших організаційних форм інтеграції бізнесу, поки ще залишається слабо розробленою стосовно вітчизняних умов, що і обумовило мету статті.

Метою статті $\epsilon$ вивчення форм стратегічної взаємодії при реалізації проектів розвитку залізничної інфраструктури.

Виклад основного матеріалу. В багатьох зарубіжних країнах, особливо європейських, накопичено солідний досвід стратегічної взаємодії в сфері енергетики, транспорту, утилізації відходів, екології, телекомунікації та ЖКГ. Загалом під стратегічним партнерством розуміють систему добровільних, довгострокових i взаємовідповідальних відносин інтеграційного типу між учасниками економічного життя, які виникають в процесі виробництва, розподілу, обміну і споживання економічного продукту й забезпечують досягнення стратегічних цілей та приводять до синергетичного приросту результативності економічної діяльності, надаючи виграш кожному партнеру [15].

Теоретичними концепціями стратегічного партнерства $€$ ресурсний підхід, теорія трансакційних витрат, ціннісна концепція, стейкхолдерська концепція (теорія зацікавлених сторін), маркетинг взаємовідносин, сітьова концепція. Формами реалізації стратегічного партнерства $\epsilon$ створення спільних підприємств, стратегічних альянсів, спільна інвестиційна діяльність, покупка акцій, ліцензій, франчайзинг та ін.

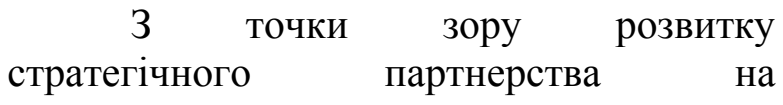
на

Вісник економіки транспорту і промисловості № 68, 2019 
залізничному транспорті найбільший інтерес має теорія зацікавлених сторін та сітьова концепція.

В основі стейкхолдерської теорії лежить ідентифікація партнерів на основі об'єднуючих їх цілей та інтересів, а також виявлення можливих методів їх досягнення. Інтереси стейкхолдерів концентруються в сфері стратегічного партнерства, існуючого в різних формах, включаючи спільне ведення бізнесу 3 основними покупцями і співробітництво 3 конкурентами. Зазначені групи можуть впливати шляхом внесення вкладу в процес стратегічних змін, спроб змінити хід стратегічного процесу та умови співпраці. Подібний тип взаємин особливо поширений в умовах невизначеності i складності зовнішнього середовища. Відповідно до стейкхолдерської концепції, ідентифікація стратегічних партнерів відбувається на основі вивчення інтересів різних суб'єктів зовнішнього оточення i виділення найбільш узгоджуваних позицій [13]. Найбільш просунутим способом взаємодіï зі стейкхолдерами $€$ сучасна технологія управління - бриджинг («наведення мостів»). Він має на увазі під собою стратегічне партнерство, яке може існувати в різних формах, аж до спільного ведення бізнесу 3 основними покупцями або співпраці з конкурентами.

Сітьовий підхід акцентує увагу керівників на побудові довгострокових стабільних відносин, сітьової взаємодії як мінімум 3 трьома сторонами на основі об'єднання учасників, що володіють стратегічною ідентичністю, а також зв'язків з їх діями та ресурсами. Це надає додаткові можливості доступу до нових технологій, ринків збуту, прискореного впровадження інновацій, формує базу для специфічних інвестицій в активи [12].

Слід зауважити, що при реалізації проектів розвитку залізничної інфраструктури основним учасником стратегічної взаємодії $є$ держава, тобто йдеться про державно-приватне партнерство (ДПП) як форму взаємодії публічних інститутів і бізнесу. Широке трактування ДПП має на увазі конструктивну взаємодію влади і бізнесу в економіці, культурі, науці, транспорті.

За даними Світового Банку, частка проектів розвитку транспортної інфраструктури становить $27 \%$ від загального числа реалізованих проектів на основі державно-приватного партнерства (ДПП), що виводить транспорт на друге місце серед інфраструктурних галузей після енергетики (39\%). Даний факт говорить про широке використання в світі форм ДПП, що застосовується при реалізації інвестиційних проектів 3 розвитку дорожнього господарства [4].

За своєю суттю проекти будівництва (реконструкціі) інфраструктурних об'єктів мають явно виражений макроекономічний ефект, оскільки забезпечують стратегічні вигоди держави в довгостроковій перспективі, що включають розвиток високоефективних, транспортно-логістичних систем, підвищення якості життя населення та вирішення соціальних завдань.

При цьому варто зазначити, що при реалізації проектів розвитку дорожньої інфраструктури важливим є збереження бюджетного фінансування, оскільки, спираючись на зарубіжний досвід, розвиток транспортної мережі тільки на основі приватних інвестицій неможливий [3]. Досвід реалізації проектів розвитку залізничної інфраструктури в Європі свідчить про те, що бюджетні кошти в середньому складають більше половини всіх витрат проекту. Виходячи 3 цього, в світовій практиці прийнято вважати, що ідею цілеспрямованого залучення фінансових ресурсів 3 приватного сектора в сферу відповідальності державного сектора відображає саме механізм ДПП.

Згідно із законом України «Про державно-приватне партнерство» державно-приватне партнерство розглядається як співробітництво між державою Україна, АР Крим, територіальними громадами та юридичними особами, крім державних та

Вісник економіки транспорту і промисловості № 68, 2019 
комунальних підприємств, що здійснюється на основі договору та відповідає ознакам державно-приватного партнерства [1].

До ознак ДПП належать:

1) створення та/або будівництво (нове будівництво, реконструкція, реставрація, капітальний ремонт та технічне переоснащення) об'єкта ДПП та/або управління (користування, експлуатація, технічне обслуговування) таким об'єктом;

2) довготривалість відносин (від 5 до 50 років);

3) передача приватному партнеру частини ризиків у процесі здійснення ДПП;

4) внесення приватним партнером інвестицій в об'єкт ДПП [1].

Закон України «Про державноприватне партнерство» надає можливість реалізувати проект на умовах механізму ДПП шляхом укладення низки договорів, зокрема: концесійного договору; договору управління майном (виключно за умови передбачення інвестиційних зобов'язань приватного партнера); договору про спільну діяльність; інших договорів [1].

Державно-приватне партнерство застосовується в таких сферах: будівництво та/або експлуатація автострад, доріг, залізниць, злітнопосадкових смуг на аеродромах, мостів, шляхових естакад, тунелів і метрополітенів, морських i річкових портів та їх інфраструктури.

Розглянемо сучасний стан залізничної інфраструктури та форми стратегічного партнерства в контексі реалізації проектів розвитку залізничної інфраструктури. 32016 року при Міністерстві інфраструктури України працює Проектний офіс 3 питань ДПП в інфраструктурі «SPILNO». За даними SWOT-аналізу, проведеного «SPILNO», основними сильними сторонами залізничної інфраструктури $є$ розвинута залізнична мережа, велика пропускна спроможність, відносно низька собівартість перевезень, прибутковість вантажних перевезень [11].

До слабких сторін належать незавершена реформа, що передбачає розділення інфраструктури та транспортних послуг, відсутність механізму участі приватного партнера у побудові залізничної інфраструктури, заборона на концесію магістральних колій, збитковість пасажирських перевезень та перехресне субсидування їх за рахунок вантажних, бюрократичність процедур оформлення вантажів при міжнародних перевезеннях.

Можливості при реалізації проектів ДПП на залізничному транспорті України полягають у наявності виробничих потужностей для відновлення залізничного парку, значної кількості незадіяної залізничної інфраструктури. Проте зовнішні загрози створюють значні ризики реалізації проектів розвитку інфраструктури через можливість незадовільної якості надання послуг приватним партнером, технічні аварії через незадовільний стан інфраструктури загального користування, зниження безпеки перевезень тощо, ринкові та фінансові ризики [11].

Використання механізму ДПП, теоретично, повинно задовольняти інтереси всіх трьох зацікавлених сторін, а саме: інтерес держави, інтерес приватного сектора, інтерес споживачів. Практично ж, досить складно спрогнозувати ефективність обраної тієї чи іншої форми партнерства в інфраструктурою. Результати і витрати можуть носити складний, багатовимірний характер, в ряді найрізноманітніших кількісних і якісних показників. Такими показниками можуть бути економічна, соціальна і бюджетна ефективність від застосування механізму ДПП в управлінні виробничої та невиробничої інфраструктурою [17].

За даними центральних та місцевих органів виконавчої влади в Україні станом на 01.07.2019 на засадах ДПП укладено 186 договорів, 3 яких реалізується 52

Вісник економіки транспорту і промисловості № 68, 2019 
договори (35 - договорів концесії, 15 договорів про спільну діяльність, 2 - інші договори), 134 договори не реалізується (4 договори - закінчено термін дії, 17 договорів - розірвано, 113 договорів - не виконується) [5]. Як видно 3 наведених даних, проекти ДПП в нашій країні не $\epsilon$ успішними. Понад дві третини проектів спіткала невдача через високі збитки та розірвання контрактів. I це справді забагато, бо, враховуючи неістотну варіацію між різними групами країн за рівнем доходів, відсоток невдач для країн із низьким рівнем доходів не перевищував $7 \%$, тоді як для країн із високим рівнем доходів був нижчим за 4\% [10].

За думкою фахівців, одним 3 суттєвих недоліків реалізації проектів ДПП є висока вартість, що випливає зі складності процесу. Для галузі транспорту технологічні переваги бізнесу відходять на другий план і більшого значення набувають навички управління компаніями. Зокрема, відсоток успіху проектів ДПП є вищім для проектів, ініційованих державним партнером, порівняно 3 ініційованими приватним: 98\% проти 76\% для країн з низькім рівнем доходів і 99\% проти 90\% для країн 3 високим рівнем доходів [10].

3 огляду на високий ступінь зносу виробничих засобів залізничного транспорту України, питання прискорення оновлення рухомого складу та інфраструктури вітчизняного залізничного комплексу стоїть сьогодні досить гостро.

В умовах потреби у великих обсягах фінансових ресурсів і водночас нестачі власних ресурсів на оновлення інфраструктури вітчизняного залізничного комплексу, концепція державноприватного партнерства являє собою альтернативу приватизації життєво важливих об'єктів державної власності, які мають стратегічне значення i застосовується при обмеженості фінансових можливостей держави для розвитку інфраструктури залізничного транспорту. Перспективи застосування ДПП для оновлення інфраструктури вітчизняного залізничного комплексу досить широкі. Це утримання пасажирських вокзалів, невеликих приміських станцій, вантажних станцій 3 малими обсягами роботи, малодіяльних ділянок.

Основним чинником, який стримує розвиток державно-приватного партнерства в транспортній галузі України, являється слабка нормативноправова база. Враховуючи і так достатню зарегульованість транспортної галузі та усі складнощі, пов'язані 3 проходженням бюрократичних процедур, приватний бізнес негативно відноситься до ДПП. [9].

Практика показує, що в Україні для інвесторів головне навіть не податкові чи кредитні пільги, а земля і підготовлена інфраструктура. Однак на сьогоднішній день в країні немає як таких спеціалізованих структур, які координують реалізацію інфраструктурних проектів - залучення позабюджетного фінансування, роботу 3 інвесторами; відсутня проектна практика.

Варто зазначити, однією 3 особливостей управління інфраструктурними проектами $\epsilon$ те, що 3 метою підвищення ефективності управління та фінансової прийнятності проект зазвичай ділиться на кілька субпроектів (планування, проектування, будівництво, експлуатація). Але транспортна інфраструктура являє собою мережу, яка використовується для здійснення перевезень, причому кожному ii елементу притаманні свої характеристики, i приватні інвестори повинні бути впевнені, що всі необхідні для старту або реалізації проекту роботи та заходи будуть своєчасно профінансовані і проведені або їх втрати будуть компенсовані в повному розмірі [12].

Контрактними формами ДПП $\epsilon$ концесія та контракт життєвого циклу. В Законі України «Про концесію» концесія форма здійснення ДПП, що передбачає надання концесієдавцем концесіонеру права на створення та/або будівництво

Вісник економіки транспорту і промисловості № 68, 2019 
(нове будівництво, реконструкцію, реставрацію, капітальний ремонт та технічне переоснащення), та/або управління (користування, експлуатацію, технічне обслуговування) об'єктом концесії, та/або надання суспільно значущих послуг у порядку та на умовах, визначених концесійним договором, а також передбачає передачу концесіонеру переважної частини операційного ризику, що охоплює ризик попиту та/або ризик пропозиції [2].

Згідно 3 умовами «контракта життєвого циклу» держава наймає приватного партнера для розвитку інфраструктури, а потім для надання на іiі основі якісних послуг і забезпечення високого рівня доступності для користування. Дохід приватного партнера формується тільки з платежів держави за доступність інфраструктури [13]. У деяких європейських країнах цей контракт називається DBFO (Design, Build, Finance, Operate: проектування - будівництво фінансування - експлуатація / управління). За сферами відповідальності контракти життєвого циклу близькі до концесій і часто класифікуються як вид концесійної угоди по типу DBFO.

$$
\text { Контракт життєвого циклу }
$$

дозволяє оптимально узгодити витрати учасників угоди і зацікавити приватного партнера в підвищенні якості будівництва; приватний партнер, по суті, допомагає державі в здійсненні державних, соціально значущих функцій. Особливо ця перевага виявляється на прикладі інфраструктурних об'єктів (доріг, мостів, портів, аеродромів): експлуатація великої кількості подібних об'єктів не $\epsilon$ економічно виправданою і не дозволяе в розумні терміни здійснити повернення вкладених у створення об'єкта інвестицій. У той же час створення таких об'єктів може відігравати значиму соціальну роль забезпечення транспортної доступності населених пунктів, регіонів 3 високим пасажирських i вантажних потенціалом або слабо розвиненою інфраструктурою [3].
Слід зазначити, що існують і інші, альтернативні партнерству форми взаємодій, що дозволяють вирішувати аналогічні завдання, поставлені учасниками, такі як: контракти, державні замовлення, тендери та інші договірні форми цивільно-правових відносин між господарюючими суб'єктами. Але при всій можливій різноманітності форм взаємодій, вони покликані забезпечити певну вигоду; проте ефект для кожного 3 учасників кращий саме при реалізації стратегічного партнерства.

\section{Висновки та перспективи}

подальших досліджень. Стратегічне партнерство являє собою одну з найбільш гнучких форм інтеграції компаній, що володіє рядом істотних відмітних ознак. Стратегічне партнерство базується на трьох фундаментальних аспектах: передбачає спільне створення нової цінності; зв'язок між учасниками спрямований на майбутнє, відкриває нові можливості i варіанти розвитку; партнерство неможливо контролювати формальними системами, але воно вимагає системи міжособистісних зв'язків i внутрішніх інфраструктур. Формами реалізації стратегічного партнерства $\epsilon$ створення спільних підприємств, стратегічних альянсів, спільна інвестиційна діяльність, покупка акцій, ліцензій, франчайзинг.

Реалізація проектів розвитку залізничної інфраструктури здійснюється на умовах механізму ДПП шляхом укладення концесійного договору; договору управління майном; договору про спільну діяльність; інших договорів. Можливості при реалізації проектів ДПП на залізничному транспорті України полягають у наявності виробничих потужностей для відновлення залізничного парку, значної кількості незадіяної залізничної інфраструктури. Перспективами застосування ДПП для оновлення інфраструктури вітчизняного залізничного комплексу $\epsilon$ утримання пасажирських вокзалів, невеликих приміських станцій, вантажних станцій 3 
малими обсягами роботи, малодіяльних ділянок. У зв'язку 3 великою капіталоємністю переважної більшості інфраструктурних проектів їх реалізація 3 використанням підходу, заснованого на ДПП, вимагає від приватної сторони наявності достатнього обсягу фінансових ресурсів. Саме тому часто в проектах ДПП з'являється третя сторона - кредитори (фінансуюча організація: Світовий банк, Міжнародна фінансова корпорація, Європейський банк реконструкції i розвитку, комерційні банки та інші інституціональні інвестори).

Будь-яка взаємодія підприємств повинна бути орієнтована на досягнення довгострокової ефективності, яка передбачає постійну зміну стану підприємства, перехід від одного рівня розвитку до іншого, дозволяє зберегти стійке положення господарюючого суб'єкта у зовнішньому середовищі.

Ефективність застосування ДПП при реалізації проектів розвитку залізничної інфраструктури та визначення критеріїв ефективності управління транспортною інфраструктурою $\epsilon$ перспективним напрямом подальших досліджень.

\section{ПЕРЕЛІК ВИКОРИСТАНИХ ДЖЕРЕЛ}

1 Закон України «Про державноприватне партнерство» від 2010 р. 2404 VI,

Редакція від 20.10.19, https://zakon.rada.gov.ua/laws/show/2404-17

2 Закон України «Про концесію» від 03.10 .2019 p.

$155-\mathrm{IX}$ https://zakon.rada.gov.ua/laws/show/155-20/

3 Алешина И. А. Эффективный механизм реализации проектов развития транспортной инфраструктуры региона / И. А. Алешина, Т. М. Геращенкова // Известия Тульского государственного университета. Экономические юридические науки. - 2016. - С. 12-20.

4 Гребешкова О. М. Проектний підхід до формування стратегічних партнерств підприємств / O. М. Гребешкова, Г. В. Махова // Збірник наукових праць Черкаського державного технологічного університету. Серія: Економічні науки. - 2009. - Вип. 22., ч. 1. - C. 23-27.

5 Державно-приватне партнерство в Україні 2019. Фонд підтримки винаходів Мінекономрозвитку

peсурс]. - Режим доступу: https://www.sfii.gov.ua/.

6 Дикань В. Л. Розвиток економіки України на основі принципу рівноправності відносин держави, бізнесу та суспільства/ В. Л. Дикань, А. В. Толстова // Вісник економіки транспорту і промисловості. - 2018. № 63. - С. 9-19.

7 Дикань В. Л. Удосконалення механізмів державного управління розвитком залізничної галузі України у євроінтеграційному векторі /В. Л. Дикань, Г. С. Островерх //Вісник економіки транспорту і промисловості. - 2018. - № 62. - C. 11-19.

8 Єлагін Ю. В. Реформування Укрзалізниці: стан і особливості / Ю. В. Єлагін, Д. І. Брильов, Л. А. Зубарєва // Вісник економіки транспорту i промисловості. - 2018. -№ 63. - С. 75-82.

9 Єлагін Ю. В. Стан і оновлення рухомого складу в умовах реформування Укрзалізниці / Ю. В. Слагін, Ю. В. Глущенко, Л. В. Цапко // Вісник економіки транспорту і промисловості. 2018. -№ 64. - C. 209-216.

10 Затворницька О. Державноприватне партнерство: час вчитися на помилках [Електронний ресурс]. - Режим доступу: https://dt.ua/macrolevel/derzhavnoprivatne-partnerstvo-chas-vchitisya-napomilkah-289689_.html

11 Інформаційно-аналітичні матеріали SPILNO / Міністерство інфраструктури України [Електронний pecypc]. - Режим доступу: https://mtu.gov.ua/content/informaciynoanalit ichni-materiali-i.html

12 Королева Е. В. Стратегические альянсы: зарубежный опыт и российские особенности/ Е. В. Королева // Российский внешнеэкономический вестник. - 2009. - 
№ 5. - C. 3-13. $\begin{array}{ccc}13 & \text { Малицкая } & \text { E. A. } \\ \text { Организационно-экономический механизм }\end{array}$ управления инфраструктурными проектами (на примере железнодорожного транспорта) / Е. А. Малицкая // Стратегия развития экономики. - 2012. - № 40 (181) - C. 37-49.

14 Овчиннікова В. О. Трансформація теорії стратегічного управління розвитком залізничного транспорту / В. О. Овчіннікова //Інтелект XXI. - 2017. - № 5. - C. 53-57.

15 Токмакова I. В. Сутність стратегічного партнерства на залізничному транспорті/ I. В. Токмакова // Вісник економіки транспорту і промисловості. - 2013. - № 41. - С. 130133.

16 Чи є майбутнє в залізничного транспорту України? [Електронний ресурс]. - Режим доступу: https://www.slideshare.net/UIFuture/ss128087151

17 Шань Ч. Формирование показателей оценки эффективности ГЧП в транспортной отрасли КНР / Чун Шань // Transport business in Russia. - 2015. - №5. - C. 122-124.

18 Шраменко О. В. Стратегічне партнерство як шлях укріплення виробничого потенціалу локомотивного господарства/ О. В. Шраменко, У.В. Монакова // Вісник економіки транспорту і промисловості. - 2013. № 44. - C. 82-86.

19 The Global Competitiveness Report 2017-2018 // http://www3.weforum.org/ docs / GCR 20172018/05 Full Report/ The Global Competitiveness Report 2017\%E2\%80\%932018.pdf

\section{REFERENCES}

1 Zakon Ukrainy «Pro DerzhavnoPryvatne Partnerstvo» Vid 2010 R. 2404-VI Redaktsiia Vid 20.10.2019 [Law of Ukraine «On Public-Private Partnership»] https://zakon.rada.gov.ua/laws/show/2404-
17, accessed (20.11.2019).

2 Zakon Ukrainy «Pro koncesiyu» Vid 03.10.2019 r. 155-IX [Law of Ukraine «About the concession»] https://zakon.rada.gov.ua/laws/show/155-20/, accessed (20.11.2019).

3 Aleshina I. A., Gerashchenkova T. M. (2016) Effektivnyi mekhanizm realizatsii proektov razvitiia transportnoi infrastruktury regiona [An effective mechanism for implementing regional transport infrastructure development projects] Bulletin of Tula State University. Economic and legal sciences, pp. 12-20.

4 Hrebeshkova O. M., Makhova H. V. (2009) Proektnyi pidkhid do formuvannia stratehichnykh partnerstv pidpryiemstv [Project approach to the formation of strategic partnerships of enterprises]. Zbirnyk naukovykh prats Cherkaskoho derzhavnoho tekhnolohichnoho universytetu. Seriia: Ekonomichni nauky, no. 22, p.1, pp. 23-27.

5 Derzhavno-pryvatne partnerstvo $\mathrm{v}$ Ukraini 2019. Fond pidtrymky vynakhodiv Minekonomrozvytku [Public-Private Partnership in Ukraine 2019. Ministry of Economic Development and Development Support for Inventions] https://www.sfii.gov.ua/, accessed (20.11.2019).

6 Dykan V. L., Tolstova A. V. (2018) Rozvytok ekonomiky Ukrainy na osnovi pryntsypu rivnopravnosti vidnosyn derzhavy, biznesu ta suspilstva [The development of the economy of Ukraine based on the principle of equality of relations between the state, business and society]. The Bulletin of Transport and Industry Economics, no. 63, pp. 9-19.

7 Dykan V. L., Ostroverkh H. Ye. (2018) Udoskonalennia mekhanizmiv derzhavnoho upravlinnia rozvytkom zaliznychnoi haluzi Ukrainy u yevrointehratsiinomu vektori [Improving the mechanisms of state management of the development of the railway industry of Ukraine in the European integration vector]. The Bulletin of Transport and Industry Economics, no. 62, pp. 11-19.

8 Yelahin Yu. V., Brylov D. I.,

Вісник економіки транспорту і промисловості № 68, 2019 
Zubarieva L. A. (2018) Reformuvannia Ukrzaliznytsi: stan i osoblyvosti [Reforming Ukrzaliznytsia: Status and Features]. The Bulletin of Transport and Industry Economics, no. 63, pp. 75-82.

9 Yelahin Yu. V., Hlushchenko Yu. V., Tsapko L. V. (2018) Stan i onovlennia rukhomoho skladu $\mathrm{v}$ umovakh reformuvannia Ukrzaliznytsi [Condition and updating of rolling stock under conditions of Ukrzaliznytsya reform]. The Bulletin of Transport and Industry Economics, no. 64, pp. 209-216.

10 Zatvornytska O. Derzhavnopryvatne partnerstvo: chas vchytysia na pomylkakh [Public-private partnership: time to learn from mistakes] https://dt.ua/macrolevel/derzhavno-privatnepartnerstvo-chas-vchitisya-na-pomilkah289689_.html, accessed (20.11.2019).

11 Informatsiino-analitychni materialy SPILNO. Ministerstvo infrastruktury Ukrainy [Information and analytical materials SPILNO / Ministry of Infrastructure of Ukraine] https://mtu.gov.ua/content/informaciynoanalit ichni-materiali-i.html, accessed (20.11.2019).

12 Koroleva E. V. (2009) Strategicheskie al'yansy: zarubezhnyy opyt i rossiyskie osobennosti [Strategic alliances: foreign experience and Russian peculiarities]. Russian Foreign Economic Bulletin, no. 5, pp. 3-13.

13 Malitskaia E. A. (2012) Organizatsionno-ekonomicheskii mekhanizm upravleniia infrastrukturnymi proektami (na primere zheleznodorozhnogo transporta) [Organizational and economic mechanism for managing infrastructure projects (for example railway transport)], Economic Development Strategy, no. 40 (181), pp. 37-49.
14 Ovchynnikova V. O. (2017) Transformatsiia teorii stratehichnoho upravlinnia rozvytkom zaliznychnoho transportu [Transformation of the theory of strategic management of the development of railway transport]. Intelekt XXI, no. 5, pp. 5357.

15 Tokmakova I. V. (2013) Sutnist stratehichnoho partnerstva na zaliznychnomu transporti [The essence of the strategic partnership in railway transport]. The Bulletin of Transport and Industry Economics, no. 41, pp. 130-133.

16 Chy ye maibutnie $\mathrm{v}$ zaliznychnoho transportu Ukrainy? [Is there a future for rail transport in Ukraine?] https://www.slideshare.net/UIFuture/ss128087151, accessed (20.11.2019).

17 SHan CH. (2015) Formirovanie pokazatelei otsenki effektivnosti GCHP v transportnoi otrasli KNR [The formation of indicators for assessing the effectiveness of PPP in the transport industry of China]. Transport business in Russia, no. 5, pp. 122124.

18 Shramenko O. V., Monakova U. V. (2013) Stratehichne partnerstvo yak shliakh ukriplennia vyrobnychoho potentsialu lokomotyvnoho hospodarstva [Strategic partnership as a way to strengthen the productive capacity of locomotive economy]. The Bulletin of Transport and Industry Economics, no. 44, pp. 82-86.

19 The Global Competitiveness Report 2017-2018 // http://www3.weforum.org/ docs / GCR 20172018/05 Full Report/ The Global Competitiveness Report 2017\%E2\%80\%932018.pdf 